\title{
The relationship of shortening and strength of eggshell to some egg quality indicators and egg production in hens of different initial laying lines*
}

\begin{abstract}
Summary
The mean values of shortening force at fracture of egg found out during the five-month observation period ranged between 0.17 and $0.19 \mathrm{~mm}$ in 231 hens of seven initial laying lines and strength of eggshell ranged from $29.05 \mathrm{~N}$ to $36.46 \mathrm{~N}$. The mean values of shortening force at fracture decreased with age of hens from $0.18-0.22$ $\mathrm{mm}$ at $28 \mathrm{wk}$ of age to $0.12-0.15 \mathrm{~mm}$ at $46 \mathrm{wk}$ of age. Similarly, strength of eggshell decreased from 31.35 $37.68 \mathrm{~N}$ to $27.91-34.50 \mathrm{~N}$ in same time period. Index of shape, ratio of eggshell and albumen to total egg weight also decreased with increasing age of hens. The highest ratio of abnormal eggs was found in both Bar Plymouth Rock lines (BPR A and BPR B) - 7.5\% and 8.3\% resp. The lowest ratio was found in lines Rhode Island Red (RIR C) $-2.1 \%$ and Susex Light (SU) - $2.4 \%$. The ratio of cracked eggs ranged from $0.9 \%$ to $3.9 \%$, the ratio of double-yolked eggs was $0.5 \%-3.2 \%$ and the ratio of eggs without shell was $0.4 \%-1.5 \%$. The calculated coefficients of correlation between shortening of egg and index of shape were mainly positive with $r_{p}$ $=0.41(\mathrm{P}<0.05)$ and $\mathrm{r}_{\mathrm{p}}=0.49(\mathrm{P}<0.01)$. The correlations between shortening of egg and total number of eggs were mainly negative with $r_{p}=-0.34(P<0.05)$ and $r_{p}=-0.46 \quad(P<0.01)$. Similar correlations existed also between shortening of egg and ratio of cracked eggs, i.e. $r_{p}=-0.44(P<0.05)$ and $r_{p}=-0.46 \quad(P<0.01)$. The correlations between shortening and total number of abnormal eggs were mainly negative $r_{p}=-0.39(P<0.05)$ and $\mathrm{r}_{\mathrm{p}}=-0.53(\mathrm{P}<0.01)$.

The relationships between strength of eggshell and shortening of egg are characterized by positive correlations $r_{p}=0.40(P<0.05)$ and $r_{p}=0.55,(P<0.01)$. Positive correlations existed also between strength of eggshell and index of shape (from $r_{p}=0.37(P<0.05)$ to $r_{p}=0.59(P<0.01)$ ). Correlations between strength of eggshell and ratio of eggshell ranged from $r_{p}=0.44(P<0.01)$ to $r_{p}=0.74(P<0.01)$. Mainly negative correlations were found out between strength of eggshell and number of eggs $r_{p}=-0.34(P<0.05)$ and $r_{p}=-0.44(P<0.01)$, similarly between the strength of eggshell and cracked eggs $r_{p}=-0.40(P<0.05)$ and $r_{p}=-0.52(P<0.01)$. Negative correlations existed between strength of eggshell and total number of abnormal eggs $\left(r_{p}=-0.45\right.$ to $r_{p}=-0.53$ $(\mathrm{P}<0.01))$. This means that both eggshell shortening and strength may be used when selecting lines for egg quality.
\end{abstract}

Key Words: laying hen, shortening of eggs, strength of eggshell, index of shape, double-yolked eggs, cracked eggs, eggs without shell, correlations

\section{Zusammenfassung}

Titel der Arbeit: Beziehungen zwischen Eischalenelastizität, Eischalenfestigkeit, Kennziffern der Eiqualität und Eiproduktion bei Hennen von auf Legeleistung gezüchteten Ausgangslinien

Während einer fünfmonatigen Versuchsperiode schwankten die durchschnittlichen Werte der Eischalenelastizität untersucht an 231 Hennen aus sieben Legelinien zwischen 0,17 und 0,19 mm und die der Eischalenfestigkeit von 29,05 bis 36,46 N. Bei einem Lebensalter von 28 Wochen ergaben sich Werte für die Eischalenelastizität von 0,18 bis $0,22 \mathrm{~mm}$ zwischen den Linien und diese reduzierten sich im Alter von 46 Wochen auf 0,12 bis 0,15 $\mathrm{mm}$. Die Eischalenfestigkeit sank in ähnlicher Weise von 31,35 bis 37,68 und von 27,91 bis 34,50 in den gleichen Zeiträumen. In Abhängigkeit vom Lebensalter reduzierten sich der Formindex der Eier sowie das Verhältnis von Weißei zur Gesamteimasse. Der höchste Anteil von Eiern, die von der Norm abwichen, war bei den Linien Bar Plymouth Rock (BPR A u. BPR B) zu verzeichnen. Den niedrigsten Anteil hatten die Eier von Hennen der Linien Rhode Island Red (RIR C) mit 2,1 \% und Sussex Light (SU) mit 2,4 \%. Der Prozentsatz an Knickeiern schwankte von $0,9 \%$ bis $3,9 \%$, an Doppeleiern von $0,5 \%$ bis 3,2 \% sowie an schalenlosen Eiern 
von $0,4 \%$ bis $1,5 \%$. Die Eischalenelastizität korrelierte mit dem Formindex des Eies überwiegend positiv mit $r_{p}$ $=0,41 \quad(p<0,05)$ bzw. $r_{p}=0,49 ;(p<0,01)$. Die Korrelationen zwischen Eischalenelastizität und Gesamteizaht waren überwiegend negativ mit $r_{p}=-0,34 \quad(p<0,05)$ bzw. $r_{p}=0,46 \quad(p<0,01)$, auch zwischen der Eischalenelastizität und dem Anteil an Knickeiern nämlich von $r_{p}=-0,44$ bis $r_{p}=-0,46(p<0,01)$. Zwischen der Eischalenelastizität und der Gesamtzahl von der Norm abweichender Eier wurden Korrelationskoeffizienten von $r_{p}=0,39(p<0,05)$ bzw. $r_{p}=-0,53 \quad(p<0,01)$ ermittelt. Die Beziehung der Eischalenelastizität zur Eischalenfestigkeit werden durch die geschätzten positiven Koeffizienten von $r_{p}=0,40(p<0,05)$ bzw. $r_{p}=0,55$ $(p<0,01)$ charakterisiert. Zwischen Eischalenfestigkeit und Formindex bestanden positive Korrelationen von $r_{p}=$ $0,37(p<0,05)$ bis $r_{p}=0,59(p<0,01)$, zwischen Eischalenfestigkeit und dem Schalenanteil wurden Werte von $r_{p}=$ 0,44 bis $r_{p}=0,74 \quad(p<0,01)$ geschätzt. Überwiegend negative Korrelationen ergaben sich zwischen Eischalenfestigkeit und Gesamteizahl $\left(r_{p}=-0,34(p<0,05)\right.$ bzw. $\left.r_{p}=-0,44 ; p<0,01\right)$ sowie zwischen der Eischalenfestigkeit und dem Anteil an Knickeiern von $r_{p}=-0,40(p<0,05)$ bzw. $r_{p}=-0,52(p<0,01)$. Negative Beziehungen bestanden zwischen der Eischalenfestigkeit und der Gesamtzahl von der Norm abweichender Eier von $r_{p}=-0,45$ bis $r_{p}=-0,53(p<0,01)$. Sowohl die Eischalenfestigkeit als auch die Eischalenelastizität kann demnach für die Selektion bezüglich der Eiqualität bei Legelinien genutzt werden.

Schlüsselwörter: Legehuhn, Eischalenelastizität, Eischalenfestigkeit, Formindex, Doppeleier, Knickeier, schalenlose Eier, Korrelationen

\section{Introduction}

Interior egg quality and factors affecting it must be considered from various points of view, with regard to strength and elasticity of eggshell. Incidence of abnormal eggs, for example cracked eggs, may vary in different strains kept in identical production conditions.

ABRAHAMSSON and TAUSON (1993) found out a difference in the incidence of cracked eggs between two strains of White Leghorn hens. SCOTT and SILVERSIDES (2000) compared egg quality of ISA - White and ISA - Brown. They observed a higher ratio of egg shell in ISA-Brown hens and they also consider pleiotropic effects of eggshell colour. On the contrary, PATTERSON et al. (2001) found no significant difference between the incidence of cracked eggs in white eggshell hybrids $(5.7 \%)$ and brown eggshell hybrids (5.4\%). BRAH et al. (1992) considered genetic determination of cracked eggs; the calculated coefficients of heritability of cracked eggs incidence in two White Leghorn strains were 0.59 and 0.36 .

Interior egg quality changes during egg laying period. HARTMANN et al. (2000) found out that the difference between selection lines in ratio of yolk; yolk weight and albumen weight persisted throughout the laying period. They also present estimated heritabilities for yolk ratio, yolk weight, egg weight and albumen weight $-\mathrm{h}^{2}=0.38$, $0.22,0.34$ and 0.41 respectively. GRUNDER et al. (1991) calculated coefficients of correlation and found out that high egg production was associated with low shell quality. They also state that high body weight of hens at $365 \mathrm{~d}$ was significantly associated with high eggshell weight. On the contrary, BRAH et al. (1992) found no significant antagonistic relationship with body weight, egg number and egg weight. JOHANSSON et al. (1996) studied the possibility of increase of eggshell strength by means of selection. They carried out divergent selection for attachment strength and they suggested the possibility of improving shell strength in laying hens by selecting for increased attachment strength.

Ratio and strength of eggshell change during egg laying period, too. AIMONEN and UUSIRAUVA (1991) observed decreasing strength and ratio of eggshell with the age of hens. 


\section{Material and Methods}

The experimental group consisted of 231 hens of initial laying lines of brown egg laying hybrids Moravia. Out of the total number of 7 lines, there were three Rhode Island Red lines (RIR A, RIR B and RIR C), two Bar Plymouth Rock lines (BPR A and BPR B), one Rhode Island White line (RIW) and one Sussex Light line (SU). The hens were housed individually in the production house with cage technology. One egg of each hen was collected at the age of 28, 32, 36, 41 and $46 \mathrm{wk}$ and shortening force at fracture of egg and strength of eggshell were determined. The measurements were taken within 48 hours after laying in laboratory conditions using the tensile testing machine TIRA test 27025 , with a cross head velocity $\mathrm{V} 1=10.0 \mathrm{~mm} / \mathrm{min}$ and a laboratory temperature $\mathrm{t}=22{ }^{\circ} \mathrm{C}$. In total, 1155 eggs were examined during a fivemonth observation period. The index of shape was calculated for each egg (width of egg/length of egg x 100). Each egg was assigned a degree of brown colour intensity according to our own 12-grade scale. Then the eggs were broken and the ratios of eggshell, albumen and yolk to the total egg weight were determined.

The egg production of hens was monitored in the control of production period from 125 to $250 \mathrm{~d}$ of age; the total number of laid eggs, the average weight of eggs laid during the period between 180 and $190 \mathrm{~d}$ and body weight of hens at $210 \mathrm{~d}$ of were calculated. Number of abnormal eggs (total defects) was also monitored during the control of production period: the total number of abnormal eggs, number of cracked eggs, number of double-yolked eggs and eggs without shell.

The measured parameters (shortening force at fracture and strength of eggshell, egg quality and production parameters) were statistically analysed, the differences between the lines were tested by t-test. The correlations were defined by using the calculated phenotypical correlations.

\section{Results}

The mean values of shortening and strength of eggshell, egg quality parameters, the total number of eggs and the number of abnormal eggs laid during the control of production period, the mean egg weight at the age between 180 and $190 \mathrm{~d}$ and body weight at $210 \mathrm{~d}$ of age in hens of seven experimental lines are shown in Table 1.

The mean shortening force at fracture ranged from $0.17 \mathrm{~mm}$ (lines RIR A, RIR C and RIW) to $0.19 \mathrm{~mm}$ (line BPR A). The dynamics of shortening of eggs of hens at the age between 28 and $46 \mathrm{wk}$ is shown in Figure 1. While at the beginning of the period (28 to $32 \mathrm{wk}$ of age) the mean values of shortening were about $0.20 \mathrm{~mm}$, they decreased to values around $0.14 \mathrm{~mm}$ at $46 \mathrm{wk}$ of age. Similar dynamics of the strength of eggshell is shown in Figure 2. At the beginning ( $28 \mathrm{wk}$ ), the mean value of strength of eggshell was $35.38 \mathrm{~N}$, at the end (46 wk of age) it decreased to $31.86 \mathrm{~N}$. The highest mean strength of eggshell was found in RIR B line $(36.46 \mathrm{~N})$ and the lowest in RIR A line $(29.05 \mathrm{~N})$.

The mean index of egg shape ranged from 74.38 (hens of RIW line) to 77.59 (hens of RIR B line); the dynamics of the index of shape of the eggs is shown in Figure 3. The mean values of index decreased with age from 77.15 at 28 wk to 74.94 at 46 wk of age. Eggshell colour intensity varied considerably among lines. The most intensive eggshell colour (5.03) was found in RIR C and the lightest shell colour was found in hens of both BPR lines (10.45 - BPR A and 11.17 - BPR B). The differences were also 
found in the eggshell to total egg weight ratio among lines. While the lowest ratio was found in eggs of RIR A hens $(8.6 \%)$, the highest ratio was found in line RIR C $(9.4$ $\%$ ). The dynamics of eggshell ratio during the observation period is shown in Figure 4. The mean values of eggshell ratio decreased with age of hens. The highest mean values were found at 28 and $32 \mathrm{wk}$ of age (9.4\%) and the lowest at $46 \mathrm{wk}$ of age $(8.9 \%)$.

\section{Table 1}

Average values of quantitative indicators of eggs, shortening, strenght of eggs (force at the fracture), laying eggs, egg weight, body weight and ratio of abnormal eggs in the hens of seven initial laying lines (33 hens in the each line) - in the age from 140 to 250 days (Durchschnittswerte von Eischalenelastizität, Eischalenfestigkeit Gesamteizahl, Eigewicht, Körpergewicht und von der Norm abweichender Eier bei Hennen von sieben Legelinien im Alter von 125 bis 250 Tagen)

\begin{tabular}{|c|c|c|c|c|c|c|c|c|}
\hline Line & & $\begin{array}{c}\text { Shortening } \\
(\mathrm{mm})\end{array}$ & $\begin{array}{c}\text { Strength } \\
\text { (N) }\end{array}$ & $\begin{array}{c}\text { Index } \\
\text { of shape }\end{array}$ & $\begin{array}{l}\text { Intensity } \\
\text { of colour } \\
\text { of shell }\end{array}$ & $\begin{array}{c}\text { Ratio } \\
\text { of shell } \\
(\%)\end{array}$ & $\begin{array}{c}\text { Ratio } \\
\text { of albumen } \\
(\%)\end{array}$ & $\begin{array}{c}\text { Ratio } \\
\text { of yolk } \\
(\%)\end{array}$ \\
\hline \multirow[t]{2}{*}{ RIR A } & $\mathbf{x}$ & 0.17 & 29.05 & 74.44 & $9.32^{\mathrm{a}}$ & 8.6 & 62.3 & 29.1 \\
\hline & $\mathbf{S}_{\mathbf{x}}$ & 0.03 & 3.79 & 2.67 & 1.64 & 0.48 & 1.27 & 1.27 \\
\hline \multirow[t]{2}{*}{ RIR B } & $\mathbf{x}$ & 0.18 & 36.46 & 77.59 & $9.86^{c}$ & 9.3 & 63.0 & 27.7 \\
\hline & $\mathbf{s}_{\mathbf{x}}$ & 0.02 & 3.63 & 2.02 & 1.02 & 0.45 & 1.40 & 1.13 \\
\hline \multirow[t]{2}{*}{ RIR C } & $\mathbf{x}$ & 0.17 & 32.66 & 74.93 & $\begin{array}{c}\text { a,b,c,d,e } \\
5.03\end{array}$ & 9.4 & 60.6 & 30.0 \\
\hline & $\mathbf{S}_{\mathbf{x}}$ & 0.03 & 4.64 & 2.98 & 1.18 & 0.34 & 1.44 & 1.35 \\
\hline \multirow[t]{2}{*}{ BPR A } & $\mathbf{x}$ & 0.19 & 35.80 & 77.28 & $10.45^{\mathrm{d}}$ & 9.2 & 61.3 & 29.4 \\
\hline & $\mathbf{S}_{\mathbf{x}}$ & 0.02 & 4.26 & 1.62 & 0.98 & 0.49 & 1.53 & 1.48 \\
\hline \multirow[t]{2}{*}{ BPR B } & $\mathbf{x}$ & 0.18 & 33.56 & 75.59 & $11.17^{\mathrm{e}}$ & 8.8 & 61.8 & 29.4 \\
\hline & $\mathbf{S}_{\mathbf{x}}$ & 0.01 & 4.29 & 2.66 & 0.99 & 0.51 & 1.62 & 1.38 \\
\hline \multirow[t]{2}{*}{ RIW } & $\mathbf{x}$ & 0.17 & 34.08 & 74.38 & $9.91^{\mathrm{b}}$ & 9.3 & 62.0 & 28.7 \\
\hline & $\mathbf{S}_{\mathbf{x}}$ & 0.02 & 3.77 & 1.69 & 1.54 & 0.62 & 2.28 & 1.82 \\
\hline \multirow[t]{2}{*}{ SU } & $\mathbf{x}$ & 0.18 & 32.70 & 76.44 & 7.77 & 8.8 & 61.8 & 29.3 \\
\hline & $\mathbf{s}_{\mathbf{x}}$ & 0.02 & 4.59 & 2.01 & 1.40 & 0.42 & 1.19 & 1.25 \\
\hline \multirow[b]{2}{*}{ Line } & & Total & Egg & \multicolumn{4}{|c|}{ Ratio of abnormal eggs } & Body \\
\hline & & $\begin{array}{l}\text { Number } \\
\text { of eggs } \\
\text { (pieces) }\end{array}$ & weight & $(\%)$ & $\begin{array}{c}\text { Two } \\
\text { yolks } \\
(\%)\end{array}$ & $\begin{array}{c}\text { Without } \\
\text { shell } \\
(\%)\end{array}$ & $\begin{array}{c}\text { Total } \\
\text { defects } \\
(\%)\end{array}$ & $\begin{array}{c}\text { weight } \\
(\mathrm{kg})\end{array}$ \\
\hline \multirow[t]{2}{*}{ RIR A } & $\mathbf{x}$ & 90.23 & 52.89 & 1.7 & 1.4 & 0.6 & 3.7 & 2.36 \\
\hline & $\mathbf{S}_{\mathbf{x}}$ & 14.89 & 2.39 & 2.31 & 1.61 & 1.38 & 5.28 & 0.20 \\
\hline \multirow[t]{2}{*}{ RIR B } & $\mathbf{x}$ & 85.13 & 52.65 & 2.7 & 1.1 & 1.5 & 5.4 & 2.12 \\
\hline & $\mathbf{S}_{\mathbf{X}}$ & 7.04 & 3.41 & 2.73 & 1.29 & 1.94 & 5.87 & 0.12 \\
\hline \multirow[t]{2}{*}{ RIR C } & $\mathbf{x}$ & 96.93 & 54.72 & 0.9 & 0.7 & 0.5 & 2.1 & 2.00 \\
\hline & $\mathbf{S}_{\mathbf{x}}$ & 10.36 & 2.35 & 1.48 & 0.81 & 1.32 & 3.61 & 0.22 \\
\hline \multirow[t]{2}{*}{ BPR A } & $\mathbf{x}$ & 88.19 & 51.01 & 3.7 & 2.8 & 1.0 & 7.5 & 1.88 \\
\hline & $\mathbf{S}_{\mathrm{x}}$ & 11.67 & 3.66 & 3.94 & 2.08 & 1.13 & 7.02 & 0.13 \\
\hline \multirow[t]{2}{*}{ BPR B } & $\mathbf{x}$ & 75.17 & 52.68 & 3.9 & 3.2 & 1.2 & 8.3 & 2.15 \\
\hline & $\mathbf{S}_{\mathbf{x}}$ & 6.64 & 2.91 & 4.20 & 3.10 & 1.58 & 8.56 & 0.16 \\
\hline \multirow[t]{2}{*}{ RIW } & $\mathbf{x}$ & 97.27 & 53.91 & 1.9 & 2.9 & 1.1 & 5.9 & 1.96 \\
\hline & $\mathbf{S}_{\mathbf{x}}$ & 8.58 & 3.06 & 2.41 & 3.29 & 1.40 & 6.82 & 0.12 \\
\hline \multirow[t]{2}{*}{ SU } & $\mathbf{x}$ & 89.77 & 50.39 & 1.5 & 0.5 & 0.4 & 2.4 & 2.15 \\
\hline & $\mathbf{s}_{\mathrm{x}}$ & 12.84 & 2.50 & 1.68 & 0.92 & 0.92 & 3.42 & 0.26 \\
\hline
\end{tabular}




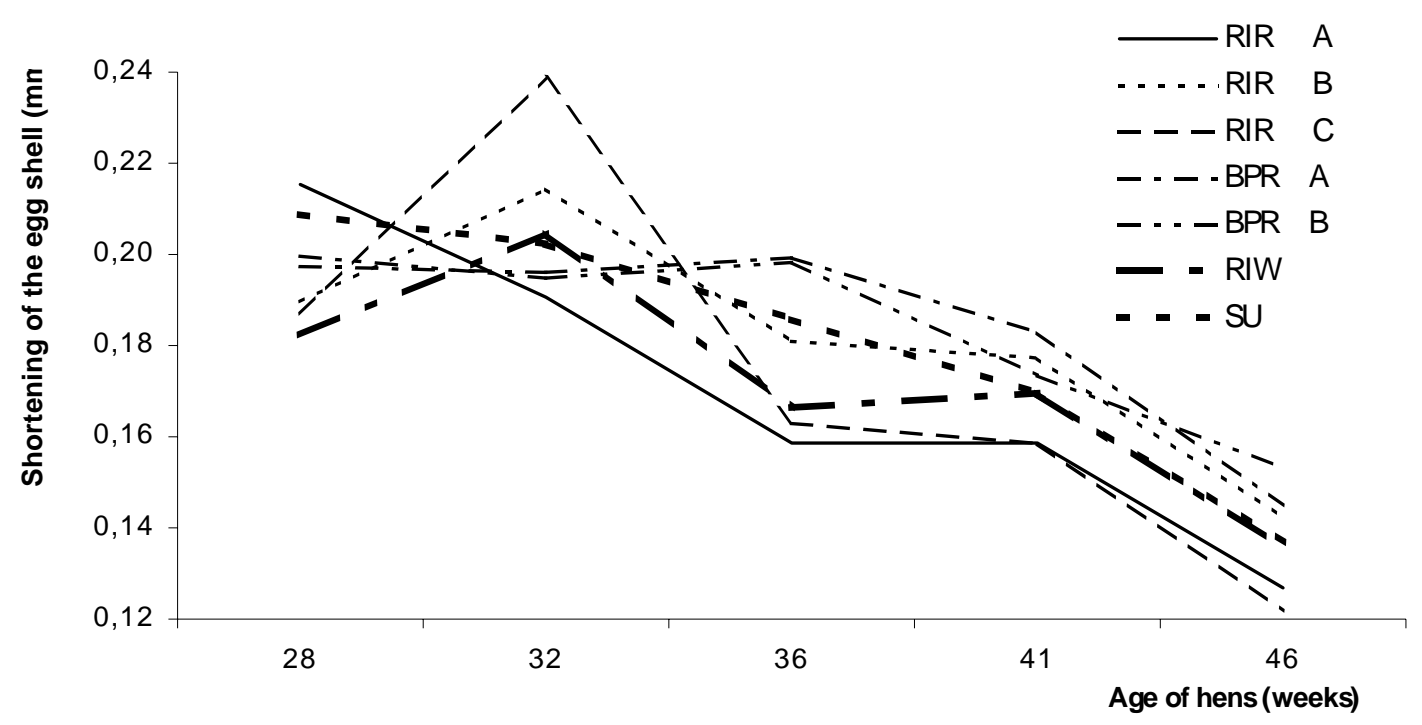

Fig. 1: The dynamics of the shortening of the egg shell in the hens of seven laying lines ( from 28 to 46 weeks of age) (Die Entwicklung der Eischalenelastizität bei Hennen von sieben Legelinien im Alter von 28 bis 46 Wochen)

The total number of eggs laid by $250 \mathrm{~d}$ of age significantly differed among lines, too. The lowest number of eggs was laid by BPR B hens (75.17 eggs) and the highest by RIW hens (97.27 eggs). Similarly, the mean egg weight determined at the age between 180 and 190 days differed among lines. The highest value was found in RIR C line $(54.72 \mathrm{~g})$, the lowest in SU line (50.39 g). The difference in number of abnormal eggs among lines was considerable. The highest ratio of abnormal eggs laid by the age of $250 \mathrm{~d}$ was found in hens of line BPR B (8.3\%) while the total number of laid eggs was lowest in this line. The lowest ratio of abnormal eggs was found in hens of RIR C line $(2.1 \%)$ and the ratio of cracks was also the lowest in this line $(0.9 \%)$. The highest ratio of cracked eggs was found in BPR B line (3.9\%). The highest ratio of double-yolked eggs was also found in BPR B hens (3.2\%), and the lowest one in hens of SU line (0.5 $\%)$. Similarly, SU hens had the lowest ratio of eggs without shell $(0.4 \%)$. The highest ratio of eggs without shell was found in RIR B hens (1.5\%). The lowest body weight at the age of $210 \mathrm{~d}$ was found in BPR A hens $(1.88 \mathrm{~kg})$ and the highest in RIR A hens $(2.36 \mathrm{~kg})$.

Table 2 presents the coefficients of correlation between shortening of egg (force at fracture) and egg quality parameters, total number of eggs and number of abnormal eggs laid during the control of production, mean weight of eggs laid between 180 and $190 \mathrm{~d}$ of age and body weight of hens of seven experimental lines at $210 \mathrm{~d}$ of age. The phenotypic coefficients of correlation between shortening of egg and index of egg shape were mainly positive, the coefficient of correlation in RIW line $\left(r_{p}=0.41\right)$ was statistically significant $(\mathrm{P}<0.05)$ and in line BPR B $\left(r_{p}=0.49\right)$ statistically highly significant $(\mathrm{P}<0.01)$.

The coefficients of correlation between shortening of eggs and total number of eggs were negative, in line RIR B $r_{p}=-0.34(P<0.05)$ and line $S U r_{p}=-0.40(P<0.05)$. The coefficients of correlation between egg weight and shortening were in lines RIR $\mathrm{C}$ and BPR B $r_{p}=-0.34$ and $r_{p}=0.38(P<0.05)$ and in line RIW statistically highly significant $-r_{p}=0.46(P<0.01)$. 


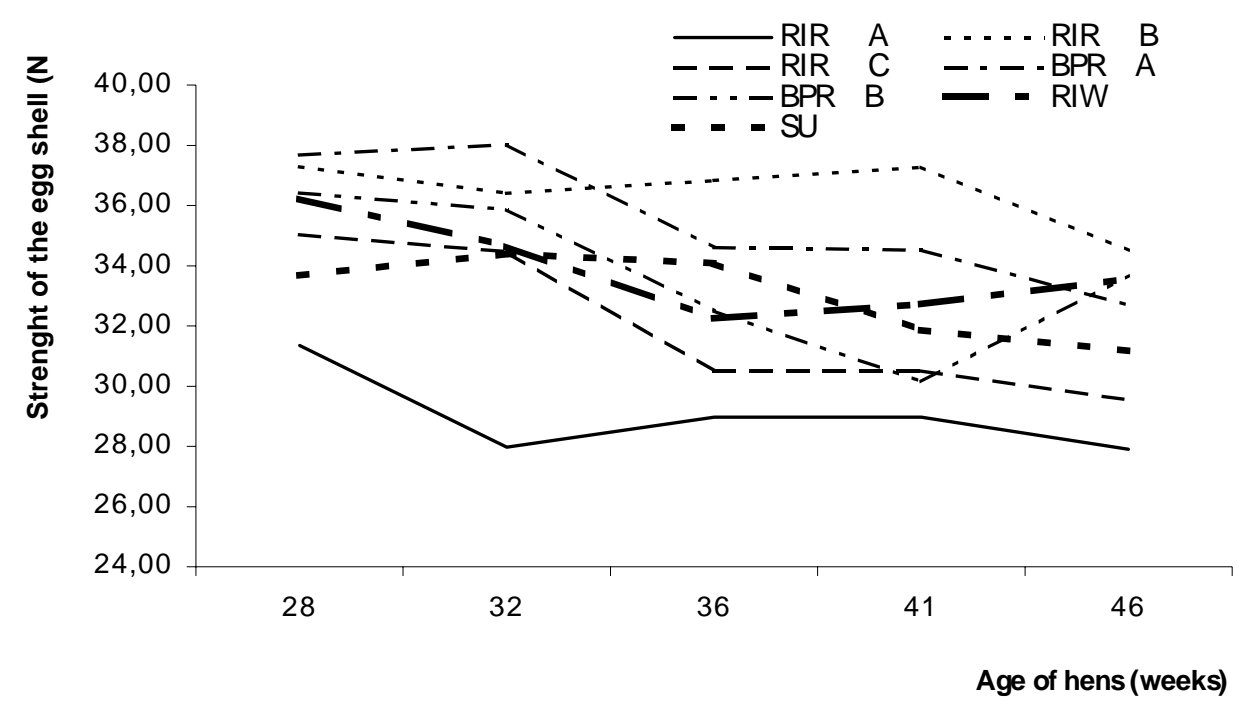

Fig. 2: The dynamics of the strenght of the egg shell in the hens of seven laying lines ( from 28 to 46 weeks of age) (Die Entwicklung der Eischalenfestigkeit bei Hennen von sieben Legelinien im Alter von 28 bis 46 Wochen)

Table 2

Estimation of correlation coefficient betwen shortening force at the fracture and the egg quality indicators, egg production, abnormal egg production and body weight in the hens of seven initial laying lines (Korrelationen zwischen Eischalenelastizität und qualitativen Kennziffern von Eiern, Gesamteizahl, von der Norm abweichender Eier und Körpergewicht bei Hennen aus sieben Legelinien)

\begin{tabular}{l|c|c|c|c|c|c|c}
\hline & \multicolumn{7}{c}{ Line } \\
\hline & RIR A & RIR B & RIR C & BPR A & BPR B & RIW & SU \\
\hline Index of shape & 0.08 & -0.05 & 0.15 & 0.21 & $0.49++$ & $0.41+$ & 0.06 \\
Intensity of colour shell & -0.05 & 0.07 & 0.05 & -0.15 & 0.04 & -0.10 & -0.03 \\
Ratio of shell & -0.10 & 0.18 & -0.25 & 0.07 & -0.01 & -0.18 & 0.05 \\
Ratio of albumen & -0.09 & -0.29 & -0.14 & 0.16 & 0.23 & 0.07 & 0.29 \\
Ratio of yolk & 0.13 & 0.29 & 0.21 & -0.19 & -0.26 & -0.02 & -0.28 \\
Total number of eggs & 0.02 & $-0.34+$ & -0.02 & -0.02 & -0.05 & -0.01 & $-0.40+$ \\
Egg weight & -0.17 & -0.05 & $-0.34+$ & -0.02 & $0.38+$ & $0.46++$ & 0.04 \\
Cracks & -0.21 & 0.09 & $-0.46++$ & -0.21 & -0.14 & $-0.44++$ & $-0.46++$ \\
Two yolks & -0.02 & 0.20 & 0.28 & 0.01 & 0.05 & $-0.40+$ & 0.21 \\
Without shell & -0.02 & -0.05 & -0.05 & 0.24 & -0.21 & -0.33 & 0.13 \\
Total defects & -0.18 & 0.09 & 0.33 & -0.10 & -0.16 & $-0.53++$ & $0.39+$ \\
Body weight & 0.11 & 0.02 & -0.03 & 0.25 & 0.20 & 0.19 & -0.06 \\
\hline + Significant $\mathrm{P}<0.05 ;++$ Significant $\mathrm{P}<0.01$
\end{tabular}

+ Significant $\mathrm{P}<0.05 ;++$ Significant $\mathrm{P}<0.01$

The correlation between shortening and percentage of cracks was mainly negative, in lines RIR C, RIW and $\mathrm{SU}\left(\mathrm{r}_{\mathrm{p}}=-0.44\right.$ and $\left.\mathrm{r}_{\mathrm{p}}=-0.46\right)$ statistically highly significant $(\mathrm{P}<0.01)$. The coefficients between shortening and total number of abnormal eggs were mainly negative, in line SU $r_{p}=-0.39(P<0.05)$ and in the line RIW $r_{p}=-0.53$ $(\mathrm{P}<0.01)$.

The calculated coefficients of correlation between strength of eggshell and egg quality parameters, total number of eggs and abnormal eggs laid in control period, mean egg weight at the age between 180 and $190 \mathrm{~d}$ and body weight of hens in seven experimental lines at $210 \mathrm{~d}$ of age are shown in Table 3. Positive coefficients of correlation were found between strength of eggshell and shortening of egg, in the line 
RIR A - $r_{p}=0.40(P<0.05)$ and in the line BPR B - $r_{p}=0.55(P<0.01)$. The coefficients of correlation between strength of eggshell and index of shape were positive, in lines RIR C $-\mathrm{r}_{\mathrm{p}}=0.37(\mathrm{P}<0.05)$ and $\mathrm{SU}-\mathrm{r}_{\mathrm{p}}=0.38(\mathrm{P}<0.05)$ and in lines RIR B, BPR B and RIW $-r_{p}=0.54$, to $r_{p}=0.59(P<0.01)$.

Table 3

Estimation of correlation coefficient betwen strenght of the egg and the egg quality indicators, egg production, abnormal egg production and body weight in the hens of seven initial laying lines (Korrelationen zwischen Eischalenfestigkeit und Eischalenelastizität, qualitativen Kennziffern von Eiern, Gesamteizahl, von der Norm abweichender Eier und Körpergewicht bei Hennen aus sieben Legelinien)

\begin{tabular}{l|c|c|c|c|c|c|c}
\hline & \multicolumn{7}{|c}{ Line } \\
\cline { 2 - 8 } & RIR A & RIR B & RIR C & BPR A & BPR B & RIW & SU \\
\hline Shortening & $0.40+$ & 0.20 & 0.23 & 0.28 & $0.55++$ & 0.20 & 0.29 \\
Index of shape & 0.19 & $0.59++$ & $0.37+$ & 0.29 & $0.56++$ & $0.54++$ & $0.38+$ \\
Intensity of colour shell & -0.27 & 0.13 & -0.02 & 0.31 & -0.24 & $-0.34+$ & -0.20 \\
Ratio of shell & 0.10 & $0.44++$ & $0.64++$ & $0.74++$ & $0.61++$ & 0.29 & 0.05 \\
Ratio of albumen & -0.10 & $-0.37+$ & -0.05 & 0.00 & -0.06 & -0.26 & 0.02 \\
Ratio of yolk & -0.07 & 0.28 & -0.11 & -0.24 & -0.16 & 0.23 & -0.27 \\
Total number of eggs & 0.18 & -0.32 & -0.30 & 0.02 & 0.01 & $-0.34+$ & $-0.44++$ \\
Egg weight & -0.30 & 0.18 & 0.14 & 0.10 & 0.28 & 0.28 & -0.05 \\
Cracks & $-0.52++$ & 0.07 & -0.29 & -0.14 & -0.29 & -0.29 & $-0.40+$ \\
Two yolks & -0.28 & 0.30 & -0.23 & -0.01 & 0.22 & $-0.43+$ & -0.32 \\
Without shell & -0.13 & 0.24 & 0.10 & $-0.38+$ & -0.09 & -0.29 & $-0.35+$ \\
Total defects & $-0.53++$ & 0.25 & -0.19 & -0.21 & -0.13 & $-0.48++$ & $-0.45++$ \\
Body weight & -0.27 & $0.37+$ & 0.04 & -0.13 & -0.18 & 0.19 & $-0.37+$ \\
\hline
\end{tabular}

+ Significant $\mathrm{P}<0.05 ;++$ Significant $\mathrm{P}<0.01$

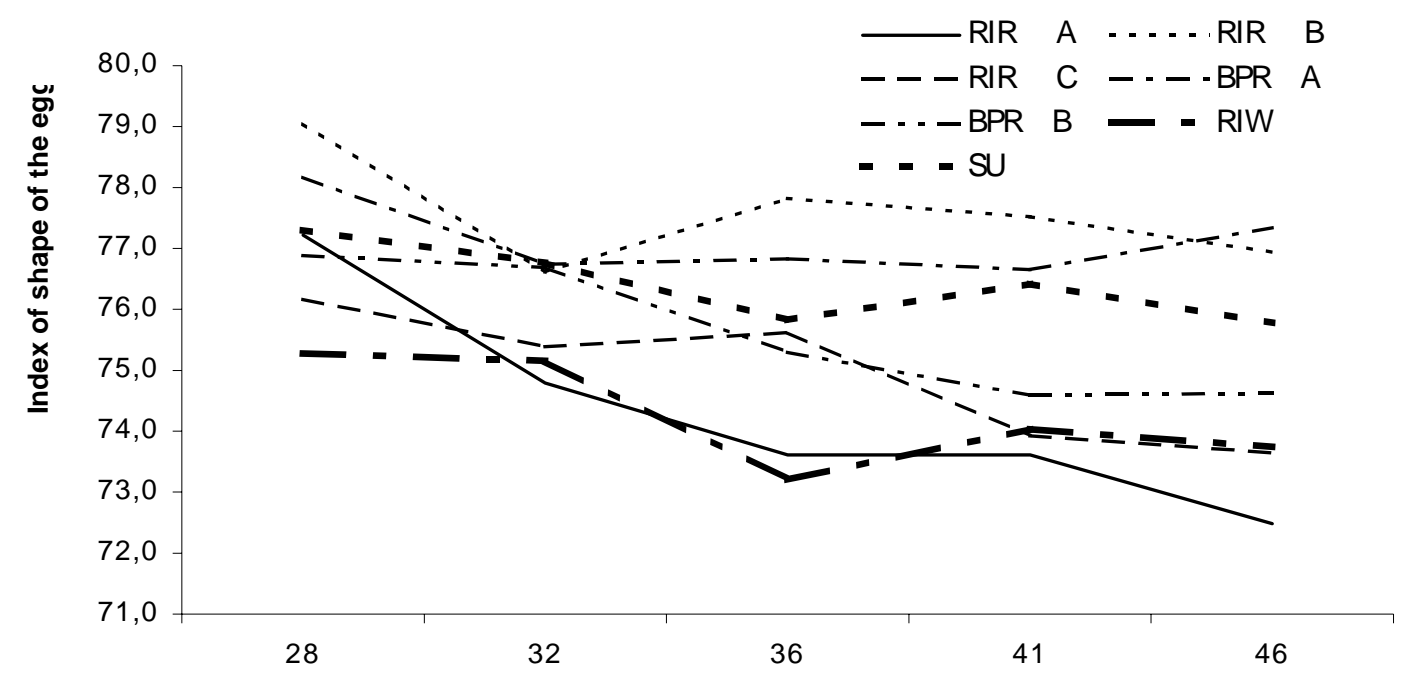

Age of hens (weeks)

Fig. 3: The dynamics of the index of shape of the eggs in the hens of seven laying lines (from 28 to 46 weeks of age) (Die Entwicklung des Formindexes des Eies bei Hennen aus sieben Legelinien im Alter von 28 bis 46 Wochen)

The coefficient of correlation between strength of eggshell and eggshell colour intensity was significant in the line RIW $r_{p}=-0.34(P<0.05)$. The correlation between strength of eggshell and ratio of eggshell was positive; the coefficients were statistically highly significant $(\mathrm{P}<0.01)$ in lines RIR B, RIR C, BPR A and BPR B and ranged from $r_{p}=0.44$ to $r_{p}=0.74$. The coefficients of correlation between strength of 
eggshell and ratio of albumen were mainly negative, the coefficient in line RIR B was $\mathrm{r}_{\mathrm{p}}=-0.37(\mathrm{P}<0.05)$.

The coefficients of correlation between strength of eggshell and number of eggs were mainly negative, in the line RIW $r_{p}=-0.34(P<0.05)$ and in the line SU $r_{p}=-0.44$ $(\mathrm{P}<0.01)$. The correlations between strength of eggshell and number of abnormal eggs were mainly negative, in lines RIR A, RIW and SU statistically highly significant $r_{p}=$ -0.45 to $r_{p}=-0.53(P<0.01)$. Between strength of eggshell and proportion of cracked eggs were calculated coefficients of correlation negative, in line $\mathrm{SU} \mathrm{r}_{\mathrm{p}}=-0.40$ $(\mathrm{P}<0.05)$ and in line RIR A $r_{p}=-0.52 \quad(P<0.01)$. The correlations between strength of eggshell and double-yolked eggs were mainly negative, the coefficient was highly significant in the hens of RIW line $r_{p}=-0.43(\mathrm{P}<0.01)$. Mostly negative were the coefficients of correlation between strength of eggshell and eggs without shell, in lines BPR A and SU statistically significant $r_{p}=-0.38$ and $r_{p}=-0.35(P<0.05)$.

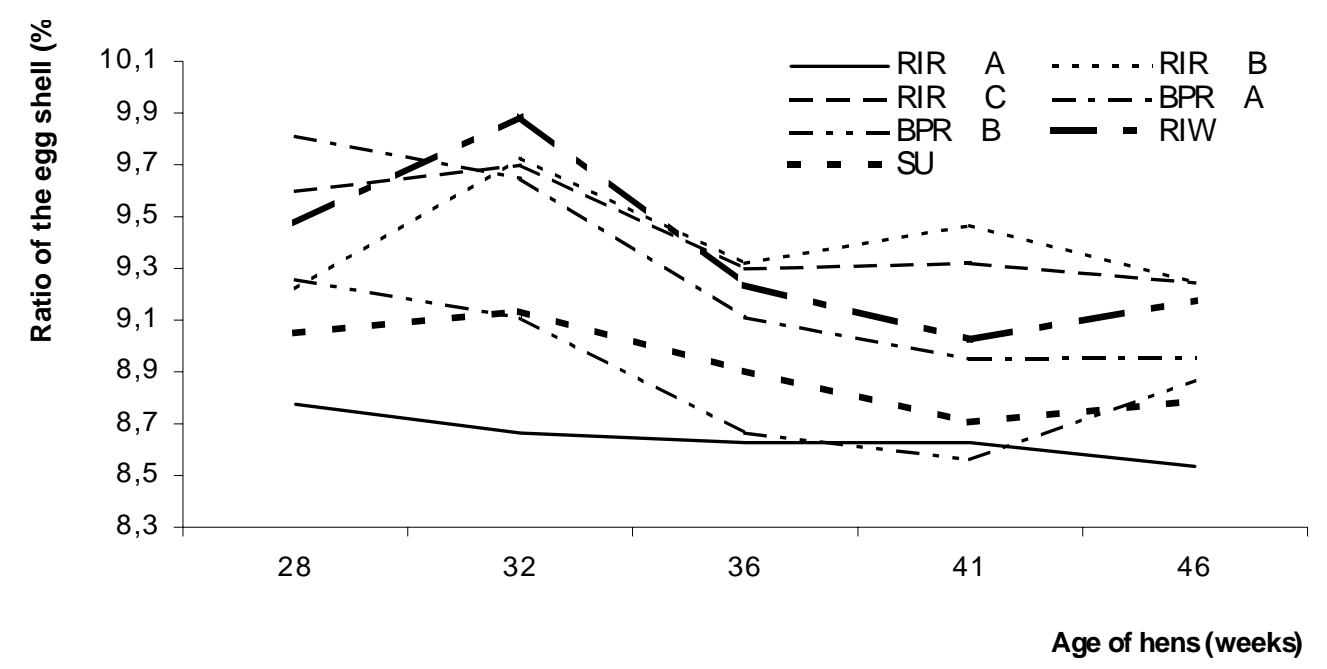

Fig. 4: The dynamics of the ratio of the egg shell in the hens of seven laying lines( from 28 to 46 weeks of age) (Die Dynamik das Verhältnis von Eischallen zur( from 28 to 46 weeks of age) (Die Dynamik das Verhältnis von Eischallen zur

\section{Discussion}

The mean values of shortening force at fracture of egg found out during the five-month observation period ranged between 0.17 and $0.19 \mathrm{~mm}$ in the experimental initial lines and strength of eggshell ranged from $29.05 \mathrm{~N}$ to $36.46 \mathrm{~N}$. At the same time, the mean values of shortening force at fracture of egg decreased with the age of hens from 0.18 $0.22 \mathrm{~mm}$ at $28 \mathrm{wk}$ of age to $0.12-0.15 \mathrm{~mm}$ at $46 \mathrm{wk}$ of age. Similarly, strength of eggshell decreased from $31,35-37.68 \mathrm{~N}$ at $28 \mathrm{wk}$ of age to $27.91-34.50 \mathrm{~N}$ at $46 \mathrm{wk}$ of age. Index of shape, ratio of eggshell and albumen to the total egg weight also decreased with increasing age of hens. These findings are in agreement with results of AIMONEN and UUSIRAUVA, 1991 and HARTMANN et al. (2000).

A statistically significant difference $(\mathrm{P}<0.05)$ was found in eggshell colour intensity between the experimental lines. The ratio of abnormal eggs to total number of eggs varied considerably between lines; however the differences were not statistically significant due to the high variability within lines. The highest ratio of abnormal eggs was found in both BPR lines (BPR A - 7.5\% and BPR B - 8.3\%) and the lowest in 
RIR C line $(2,1 \%)$ and SU line $(2.4 \%)$. The inter-line differences were also found in ratio of cracked eggs, in agreement with ABRAHAMSSON and TAUSON (1993). The lowest ratio of cracked eggs $(0.9 \%)$ was found in RIR C lines and the highest in both BPR lines (BPR A $-3.7 \%$ and BPR B $-3.9 \%$ ). The ratio of eggs without shell was lowest in SU line $(0.4 \%)$ and RIR C line $(0.5 \%)$ and highest in RIR B line -1.5 $\%$. Total number of eggs laid by $250 \mathrm{~d}$ of age ranged between 75.17 eggs (BPR B) and 97.27 eggs (RIW). Body weight at $210 \mathrm{~d}$ of age was lowest in hens of BPR A (1.88 $\mathrm{kg})$ and highest in RIR A hens $(2.36 \mathrm{~kg})$.

The calculated coefficients of correlation between shortening of egg and index of shape were mainly positive, with $\mathrm{r}_{\mathrm{p}}=0.41(\mathrm{P}<0.05)$ and $(\mathrm{P}<0.01)$. The correlations between shortening of egg and total number of eggs were mainly negative, with $r_{p}=-$ 0.34 and $r_{p}=-0.40(P<0.05)$. This result was in agreement with GRUNDER et al. (1991); however, it did not correspond with results of BRAH et al. (1992). The coefficients of correlation between shortening of egg and ratio of cracked eggs were mainly negative; the coefficients $r_{p}=-0.46$ and $r_{p}=-0.44$ were statistically highly significant $(\mathrm{P}<0.01)$. The correlations between shortening and total number of abnormal eggs were mainly negative $-r_{p}=-0.39(P<0.05)$ and $r_{p}=-0.53(P<0.01)$.

The coefficients of correlation between strength of eggshell and shortening were positive $-r_{p}=0.40(P<0.05)$, and $r_{p}=0.55(P<0.01)$. The correlation between strength of eggshell and index of shape was positive (from $r_{p}=0.37(P<0.05)$ to $r_{p}=0.59$ $(\mathrm{P}<0.01))$. The correlations between strength of eggshell and ratio of eggshell were also positive, $r_{p}=0.44$, to $r_{p}=0.74(P<0.01)$. The coefficients of correlation between strength of eggshell and number of eggs were mainly negative $-r_{p}=-0.34(P<0.05)$ and $r_{p}=-0.44(P<0.01)$. These finding are in agreement with GRUNDER et al. (1991) but they disagree with results of BRAH et al. (1992).

The correlations between strength of eggshell and cracked eggs were $-r_{p}=-0.40$ $(\mathrm{P}<0.05)$ and $r_{p}=-0.52(P<0.01)$. Mainly negative coefficients of correlation were found between strength of eggshell and double-yolked eggs $-r_{p}=-0.43(P<0.05)$. The correlations between strength of eggshell and eggs without shell were also mainly negative $-r_{p}=-0.35$ and $-0.38(P<0.05)$. Similar the coefficients of correlation between strength of eggshell and total number of abnormal eggs were mainly negative $-r_{p}=-$ 0.45 to $r_{p}=-0.53(P<0.01)$.

In conclusion, our results proved inter-line differences in shortening force at fracture of egg and strength of eggshell and these parameters decreased with age of hens. The correlations between shortening force at fracture of egg, strength of eggshell and number of laid eggs were negative. Similarly, the correlations between shortening force at fracture of egg, strength of eggshell and ratio of cracked eggs, eggs without shell and abnormal eggs to total number of eggs were negative, too. Thus, testing of shortening force at fracture and strength of eggshell can be used (in agreement with JOHANSSON et al., 1996) in selection for egg quality within laying lines on hens.

\section{References}

ABRAHAMSSON, P.; TAUSON, R.:

Effect of perches at different positions in conventional cages for laying hens of 2 different strains. Acta Agr. Scand. A - An., 43 (1993), 228 - 235

AIMONEN, E.M.J.; UUSIRAUVA, E.:

Replacement of barley by oats and enzyme supplementation in diets for laying hens. 2. Interior quality and chemical- composition of eggs. Acta Agr. Scand. A 41 (2000), 193 - 195 
BRAH, G.S.; CHAUDHARY, M.L.; SANDHU, J.S.:

Heritabilities and correlations for eggshell crack frequency, body checking, egg number and egg weight in laying hens. Brit. Poultry Sci., 33 (1992), 947 - 951

GRUNDER, A.A.; FAIRFULL, R.W.; HAMILTON, R.M.G.; THOMPSON, B.K.:

Correlations between measures of eggshell quality or percentage of intact eggs and various economic traits. Poultry Sci., 70 (1991), $1855-1860$

HARTMANN, C.; JOHANSSON, K.; STRANDBERG, E.; WILHELMSON, M.:

One - generation divergent selection on large and small yolk ratios in a White Leghorn line. Brit. Poultry Sci., 41 (2000), 280 - 286

JOHANSSON, K.; ORBERG, J.; CARLGREN, A.B.; WILHELMSON, M.:

Selection for eggshell strength in laying hens using shell membrane characteristics. Brit. Poultry Sci., 37 (1996), $757-763$

PATTERSON, P.H.; KOELKEBECK, K.W.; BELL, D.D.; CAREY, J.B.; ANDERSON, K.E.; DARRE, M.J.: Egg marketing in national supermarkets: Specialty eggs - Part 2. Poultry Sci., 80 (2001), 390 - 395

SCOTT, T.A.; SILVERSIDE, F.G.:

The effect of storage and strain of hen on egg quality. Poultry Sci., 79 (2000), $1725-1729$

Received: 2001-10-12

Accepted: 2002-04-10

Author's address

Doc. ing. LADISLAV MÁCHAL, DrSc., Doc. Ing. JANA SIMEONOVOVÁ, CSc.

Mendel University of Agriculture and Forestry Brno

Zemědělská 1

61300 Brno

Czech Republic 